\title{
UJI KONSENTRASI AIR KELAPA DAN PENYIRAMAN AIR LERI TERHADAP PERTUMBUHAN DAN HASIL UBI JALAR (Ipomoea batatas L.)
}

\author{
Yuni Sih Utami ${ }^{1 *}$, JM. Sri Hardiatmi ${ }^{2}$ Siswadi $^{2}$ \\ ${ }^{1 *}$ Mahasiswa program S1 Agroteknologi, Fakultas Pertanian, Universitas Slamet Riyadi. \\ ${ }^{2}$ Staf Pengajar Program Studi Agroteknologi, Fakultas Pertanian, Universitas Slamet Riyadi \\ 1*yunisihutami@gmail.com
}

\begin{abstract}
ABSTRAK
Penelitian tentang "Uji konsentrasi air kelapa dan penyiraman leri terhadap pertumbuhan dan hasil ubi jalar (Ipomea batatas L.)" telah dilaksanakan mulai tanggal 03 Agustus 2018 sampai 03 Desember 2018 Sekip RT 06 RW 08, Kadipiro, Banjarsari, Surakarta. Penelitian ini bertujuan untuk (1) mengetahui pengaruh dari uji konsentrasi air kelapa terhadap pertumbuhan dan hasil ubi jalar (Ipomoea batatas L.), (2) mengetahui pengaruh dari penyiraman air leri terhadap terhadap pertumbuhan dan hasil ubi jalar (Ipomoea batatas L.), (3) mengetahui pengaruh terbaik dari uji konsentrasi air kelapa dan penyiraman air leri terhadap pertumbuhan dan hasil ubi jalar (Ipomoea batatas L.) Penelitian menggunakan Rancangan Acak Kelompok (RAK) yang disusun secara faktorial. Perlakuan terdiri dari 2 faktor, masing-masing kombinasi perlakuan diulang 3 kali. Adapun kedua faktor tersebut adalah : (1) konsentrasi air kelapa (K) dengan 5 (lima) taraf yaitu: konsentrasi 0\% (K0), konsentrasi 25\% (K1), konsentrasi 50\% (K2), konsentrasi 75\% (K3), konsentrasi 100\% (K4), (2). Penyiraman air leri yang terdiri dari 2 taraf yaitu : penyiraman tanpa leri (L2) dan penyiraman diberi leri (L2) Kedua faktor perlakuan tersebut dikombinasikan sehinngga diperoleh 10 kombinasi perlakuan. Data dianalisis menggunakan Analisis Ragam, yang dilanjutkan dengan Uji Beda Nyata Jujur pada taraf $5 \%$. Hasil penelitian menunjukkan perlakuan uji konsentrasi air kelapa dan penyiraman air leri tidak berpengaruh nyata terhadap komponen pertumbuhan dan hasil tanaman ubi jalar yaitu jumlah daun, jumlah tunas, panjang sulur, jumlah umbi, volume umbi, berat umbi, berat brangkasan basah, namun pada komponen pertumbuhan yaitu jumlah daun yang mempunyai jumlah daun terbanyak yaitu pada (K1L2), pada jumlah tunas yaitu tunas terbanyak terdapat pada perlakuan (K0L2), pada panjang sulur yang memiliki sulur tanaman terpanjang yaitu pada perlakuan (K3L2), pada komponen hasil jumlah umbi yang terbanyak yaitu pada perlakuan (K4L1), pada volume umbi yang menghasilkan umbi terbesar yaitu pada perlakuan (K0L2, pada berat umbi yang memiliki hasil terbesar yaitu pada (K0L2, pada berat brangkasan basah yang menghasilkan berat terbaik yaitu pada (K2L2).
\end{abstract}

Kata Kunci : Air Kelapa, Leri, Pertumbuhan dan Hasil

\section{ABSTRACK}

Research on "Concentration of coconut water and watering of the growth and yield of sweet potato (Ipomea batatas L.)" has been carried out from 3 August 2018 to 3 December 2018 Sekip RT 06 RW 08, Kadipiro, Banjarsari, Surakarta. This study aims to (1) determine the effect of the concentration of coconut water on the growth and yield of sweet potatoes (Ipomoea batatas L.), (2) to determine the effect of watering on the growth and yield of sweet potatoes (Ipomoea batatas L.), (3) find out the best effect of the concentration of coconut water and watering of the water on the growth and yield of sweet potato (Ipomoea batatas L.) The study used a Randomized Block Design (RBD) which was arranged factorially. The treatment consisted of 2 factors, each treatment combination was repeated 3 times. The two factors are: (1) coconut water concentration $(K)$ with 5 (five) levels, namely: concentration of $0 \%(K 0)$, concentration of $25 \%(K 1)$, concentration of $50 \%(K 2)$, concentration of $75 \%(K 3)$, concentration of $100 \%$ 
(K4), (2). Watering of liquid water consisting of two levels, namely: non-watering (L2) and watering given leri (L2) Both treatment factors were combined so that 10 combinations of treatments were obtained. Data were analyzed using Variety Analysis, which was followed by an Honestly Significant Difference Test at the level of 5\%. The results showed the treatment of coconut water concentration test and watering of leri water had no significant effect on the components of growth and yield of sweet potato, namely number of leaves, number of shoots, tendrils length, tubers, tuber volume, tuber weight, wet stover weight, but on growth components that is the number of leaves which have the highest number of leaves, namely (K1L2), the number of shoots, the highest shoots are in the treatment (KOL2), in the longest tendrils that have the plant tendrils, namely treatment (K3L2). in the treatment (K4L1), the bulb volume which produced the largest tuber was in the treatment (KOL2, in the tuber weight which had the greatest yield, namely (KOL2, on the weight of wet stover which produced the best weight, namely (K2L2).

Keywords : Coconut Water, Leri Water, Growth and Yield

\section{PENDAHULUAN}

Kedudukan ubi jalar tidak kalah pentingnya dengan komoditas sumber karbohidrat yang lain. Saat ini, ubi jalar telah dimanfaatkan sebagai bahan baku industri seperti ethanol, gula sirup, alkohol maupun bahan kosmetik yang tidak hanya untuk kalangan sendiri (Indonesia), tetapi juga dalam skala dunia (Tsuno, 1980).

Pada perbanyakan secara vegetatif dengan setek batang dirasa lebih efektif, efisien, dan juga lebih ekonomis. Pemberian ZPT (Zat Pengatur Tumbuh) dimaksudkan untuk merangsang dan memacu terjadinya pembentukan akar setek sehingga perakaran setek akan lebih baik dan lebih banyak. Jenis ZPT beragam, Air kelapa telah lama dikenal sebagai salah satu sumber ZPT terutama sitokinin, auksin dan giberelin (Gardner,et al 2006).

Selain perendaman dengan menggunakan air kelapa faktor yang sangat berpengaruh dalam perawatan tanaman adalah penyiraman. salah satu Limbah yang dapat digunakan untuk penyiraman tanaman adalah leri, kandungan leri yaitu fosfor yang merupakan unsur hara makro yang sangat dibutuhkan oleh tanaman. Selain mengandung fosfor leri juga mengandung vitamin B1. Vitamin B1 memiliki kemampuan memacu pertumbuhan tanaman. Menurut Djoehana (1986) fosfor berperan dalam memacu pertumbuhan akar dan pembentukan sistem perakaran yang baik dari benih tanaman muda.

\section{METODE PENELITIAN}

Penelitian yang dilakukan menggunakan perancangan dasar Rancangan Acak Lengkap (RAL) yang disusun secara faktorial, terdiri dari dua faktor perlakuan yaitu uji konsentrasi air kelapa dan penyiraman air leri. berikut:

Adapun faktor-faktornya sebagai

Faktor 1 konsentrasi air kelapa (K) yang terdiri dari 5 macam taraf yaitu:

$\mathrm{K}_{0}$ : tanpa air kelapa $(0 \%)$

$\mathrm{K}_{1}$ : konsentrasi air kelapa $25 \%$

$\mathrm{K}_{2}$ : konsentrasi air kelapa 50\%

$\mathrm{K}_{3}$ : konsentrasi air kelapa $75 \%$

$\mathrm{K}_{4}$ : konsentrasi air kelapa $100 \%$

Faktor 2 penyiraman air leri (L) yang terdiri dari 2 macam antara lain:

$\mathrm{L}_{1}$ : tanpa Air leri

$\mathrm{L}_{2}$ : diberi Air leri

Dari kedua faktor diatas diperoleh 10 kombinasi perlakuan dan masing-masing perlakuan diulang sebanyak tiga kali sehingga ada 30 polybag, yang menghasilkan kombinasi yaitu sebagai berikut:

$\mathrm{K}_{0} \mathrm{~L}_{1}$ : perendaman tanpa air kelapa $(0 \%)$ dan penyiraman tanpa air leri

$\mathrm{K}_{0} \mathrm{~L}_{2}$ : perendaman tanpa air kelapa $(0 \%)$ dan penyiraman diberi air leri

$\mathrm{K}_{1} \mathrm{~L}_{1} \quad$ : perendaman dengan konsentrasi air kelapa $25 \%$ dan penyiraman tanpa air leri

$\mathrm{K}_{1} \mathrm{~L}_{2} \quad$ : perendaman dengan konsentrasi air kelapa $25 \%$ dan penyiraman diberi air leri 
$\mathrm{K}_{2} \mathrm{~L}_{1} \quad$ : perendaman dengan konsentrasi air kelapa $50 \%$ dan penyiraman tanpa air leri

$\mathrm{K}_{2} \mathrm{~L}_{2} \quad$ : perendaman dengan konsentrasi air kelapa $50 \%$ dan penyiraman diberi air leri

$\mathrm{K}_{3} \mathrm{~L}_{1} \quad$ : perendaman dengan konsentrasi air kelapa $75 \%$ dan penyiraman tanpa air leri

$\mathrm{K}_{3} \mathrm{~L}_{2}$ : perendaman dengan konsentrasi air kelapa $75 \%$ dan penyiraman diberi air leri

$\mathrm{K}_{4} \mathrm{~L}_{1} \quad$ : perendaman dengan konsentrasi air kelapa $100 \%$ dan penyiraman tanpa air leri
$\mathrm{K}_{4} \mathrm{~L}_{2} \quad$ : perendaman dengan konsentrasi air kelapa $100 \%$ dan penyiraman diberi air leri

Data dianalisis menggunakan analisis ragam untuk mengetahui pengaruh dari perlakuan tersebut. Analisis selanjutnya menggunakan Uji Beda Nyata Jujur (BNJ) pada taraf $5 \%$ untuk mengetahui perlakuanperlakuan yang berpengaruh dan tidak berpengaruh.

\section{HASIL}

Dari uji konsentrasi air kelapa dan penyiraman air leri terhadap pertumbuhan dan hasil ubi jalar (Ipomea batatas L.) dapat dilihat pada tabel I dan tabel II.

Tabel I. Uji Konsentrasi Air Kelapa Dan Penyiraman Air Leri Terhadap Pertumbuhan Ubi Jalar (Ipomea Batatas L.)

\begin{tabular}{ccrrr}
\hline Perlakuan & Jumlah Daun & Jumlah Tunas & Panjang Sulur & Berat Brangkasan Basah \\
\hline K0L1 & $223,00 \mathrm{a}$ & $14,00 \mathrm{a}$ & $122,67 \mathrm{a}$ & $466,67 \mathrm{a}$ \\
K0L2 & $235,67 \mathrm{a}$ & $20,00 \mathrm{a}$ & $119,33 \mathrm{a}$ & $491,67 \mathrm{a}$ \\
K1L1 & $201,00 \mathrm{a}$ & $14,67 \mathrm{a}$ & $124,00 \mathrm{a}$ & $400,00 \mathrm{a}$ \\
K1L2 & $289,00 \mathrm{a}$ & $19,00 \mathrm{a}$ & $140,00 \mathrm{a}$ & $400,00 \mathrm{a}$ \\
K2L1 & $237,33 \mathrm{a}$ & $17,33 \mathrm{a}$ & $128,00 \mathrm{a}$ & $433,33 \mathrm{a}$ \\
K2L2 & $264,00 \mathrm{a}$ & $15,67 \mathrm{a}$ & $113,67 \mathrm{a}$ & $575,00 \mathrm{a}$ \\
K3L1 & $212,67 \mathrm{a}$ & $13,33 \mathrm{a}$ & $154,00 \mathrm{a}$ & $425,00 \mathrm{a}$ \\
K3L2 & $198,33 \mathrm{a}$ & $14,33 \mathrm{a}$ & $156,67 \mathrm{a}$ & $408,33 \mathrm{a}$ \\
K4L1 & $241,00 \mathrm{a}$ & $15,33 \mathrm{a}$ & $135,33 \mathrm{a}$ & $500,00 \mathrm{a}$ \\
K4L2 & $196,33 \mathrm{a}$ & $13,00 \mathrm{a}$ & $136,00 \mathrm{a}$ & $366,67 \mathrm{a}$ \\
\hline
\end{tabular}

Keterangan : Rata-rata berat umbi tanaman yang diikuti huruf sama berarti tidak berbeda nyata.

Berdasarkan tabel I uji konsentrasi air kelapa dan penyiraman air leri tidak berpengaruh nyata terhadap komponen Tabel I. Uji Konsentrasi Air Kelapa Dan Penyiraman Air Leri Terhadap Hasil Ubi Jalar (Ipomea Batatas L.)

\begin{tabular}{cccc} 
Batatas L.) & & Volume Umbi & Berat Umbi \\
\hline Perlakuan & Jumlah Umbi & $168,98 \mathrm{a}$ & $167,87 \mathrm{a}$ \\
K0L1 & $3,33 \mathrm{a}$ & $322,58 \mathrm{a}$ & $278,4 \mathrm{a}$ \\
K0L2 & $3,00 \mathrm{a}$ & $257,27 \mathrm{a}$ & $187,85 \mathrm{a}$ \\
K1L1 & $3,67 \mathrm{a}$ & $156,83 \mathrm{a}$ & $156,83 \mathrm{a}$ \\
K1L2 & $3,33 \mathrm{a}$ & $199,51 \mathrm{a}$ & $195,21 \mathrm{a}$ \\
K2L1 & $2,67 \mathrm{a}$ & $153,31 \mathrm{a}$ & $150,12 \mathrm{a}$ \\
K2L2 & $3,00 \mathrm{a}$ & $160,27 \mathrm{a}$ & $161,39 \mathrm{a}$ \\
K3L1 & $3,67 \mathrm{a}$ & $142,20 \mathrm{a}$ & $137,66 \mathrm{a}$ \\
K3L2 & $1,33 \mathrm{a}$ & $74,14 \mathrm{a}$ & $70,76 \mathrm{a}$ \\
K4L1 & $5,00 \mathrm{a}$ & $149,65 \mathrm{a}$ & $146,09 \mathrm{a}$ \\
K4L2 & $3,00 \mathrm{a}$ &
\end{tabular}

Keterangan : Rata-rata berat umbi tanaman yang diikuti huruf sama berarti tidak berbeda nyata.

Berdasarkan tabel II uji konsentrasi air kelapa dan penyiraman air leri tidak berpengaruh nyata terhadap komponen hasil pertumbuhan tanaman ubi jalar yaitu jumlah daun, jumlah tunas, panjang sulur, dan berat brangkasan basah.

tanaman ubi jalar yaitu jumlah umbi, volume umbi, dan berat umbi. 

gambar 1.

Perkembangan jumlah daun umur 2 MST sampai dengan umur 16 MST disajikan dalam

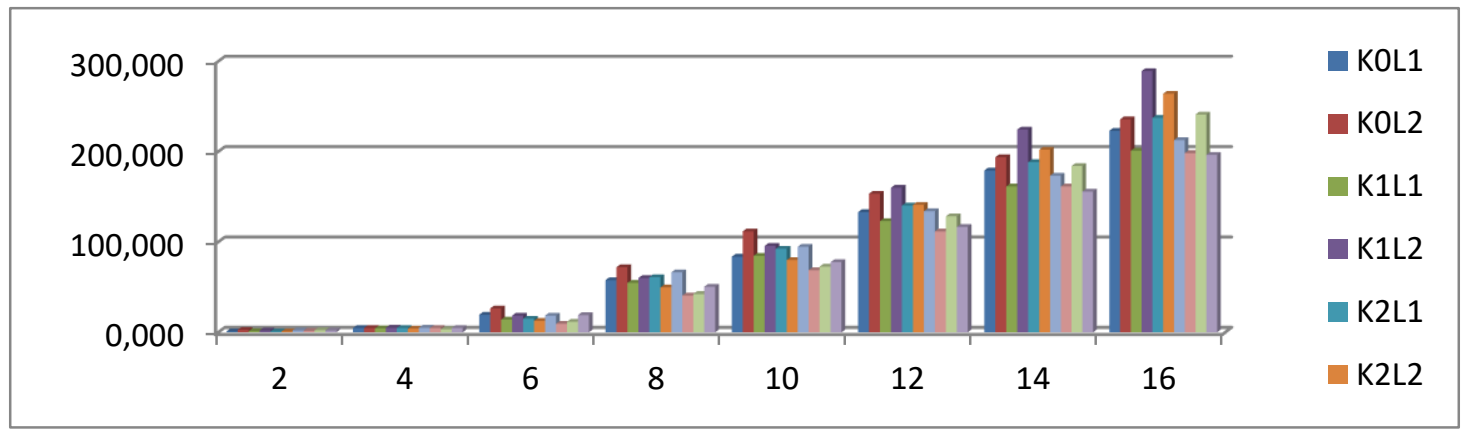

Gambar 1. Grafik Perkembangan Jumlah Daun Umur 2 MST-16 MST.

Berdasarkan hasil dari grafik gambar 1 menunjukkan bahwa jumlah daun terbaik terdapat pada perlakuan K1L2 yaitu perendaman dengan air kelapa konsentrasi $25 \%$ dan penyiraman diberi leri.

\section{PEMBAHASAN}

1. Uji konsentrasi air kelapa dan penyiraman leri terhadap pertumbuhan tanaman ubi jalar.

Berdasarkan hasil penelitian tersebut di atas diketahuai bahwa perlakuan uji konsentrasi air kelapa dan penyiraman leri tidak berpengaruh nyata terhadap komponen pertumbuhan jumlah, panjang sulur, jumlah tunas, dan berat brangkasan basah. sebagaimana terlihat pada gambar 2 , 3,4 , dan 5

Gambar 2. Diagram batang untuk jumlah daun umur 16 MST akibat perlakuan uji konsentrasi air kelapa dan penyiraman leri.

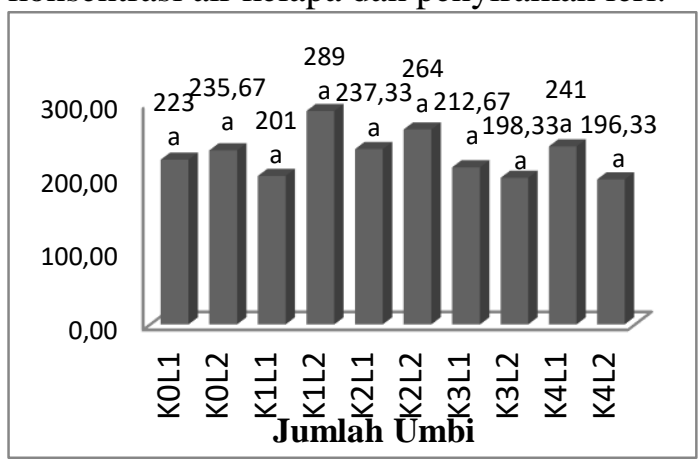

Gambar 2. Menunjukkan bahwa uji konsentrasi air kelapa 25\% dan penyiraman diberi leri (K1L2) dengan rata-rata jumlah daun 289 helai tidak berbeda nyata dengan uji konsentrasi air kelapa $100 \%$ dan penyiraman diberi leri (K4L2) dengan ratarata jumlah daun 196,33 helai hal ini diduga karena persediaan unsur hara yang ada di dalam tanah dan tanaman sudah mencukupi untuk mendukung pertumbuhan setek ubi jalar jadi tidak diperlukan penyiraman air leri hingga mendekati panen, dan juga pada penelitian (Karimah dkk., 2013) yang menyatakan air kelapa konsentrasi 100\% yang paling berpengaruh bagi pertumbuhan tanaman yaitu diteliti pada tanaman jati yang merupakan tanaman keras dan sudah berbeda spesies dengan tanaman ubi jalar.

Gambar 3. Diagram batang untuk jumlah tunas umur 16 MST akibat perlakuan uji konsentrasi air kelapa dan penyiraman leri.

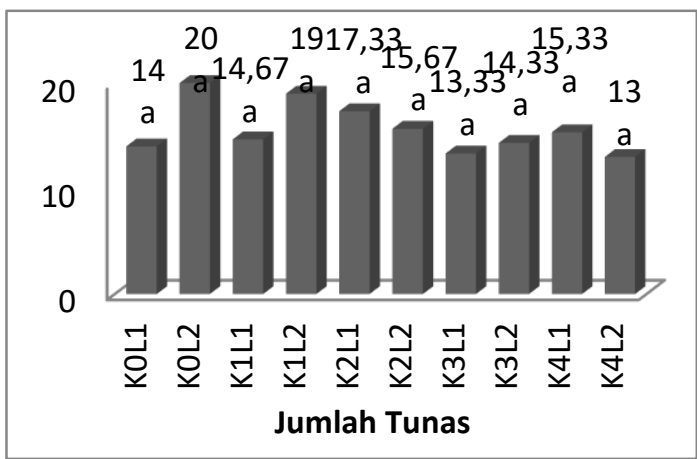

Gambar 3. Menunjukkan bahwa uji konsentrasi air kelapa 0\% dan penyiraman diberi leri (KOL2) dengan rata-rata jumlah tunas 20 batang tidak berbeda nyata dengan uji konsentrasi air kelapa $100 \%$ dan penyiraman diberi leri (K4L2) dengan ratarata jumlah tunas 13 batang hal ini diduga karena persediaan unsur hara yang ada di dalam tanah dan tanaman sudah mencukupi untuk mendukung pertumbuhan setek ubi jalar jadi tidak diperlukan penyiraman air leri hingga mendekati panen, dan juga pada penelitian (Karimah dkk., 2013) yang menyatakan air kelapa konsentrasi 100\% yang paling berpengaruh bagi pertumbuhan tanaman yaitu diteliti pada tanaman jati 
yang merupakan tanaman keras dan sudah berbeda spesies dengan tanaman ubi jalar.

Gambar 4. Diagram batang untuk panjang sulur umur 16 MST akibat perlakuan uji konsentrasi air kelapa dan penyiraman leri.

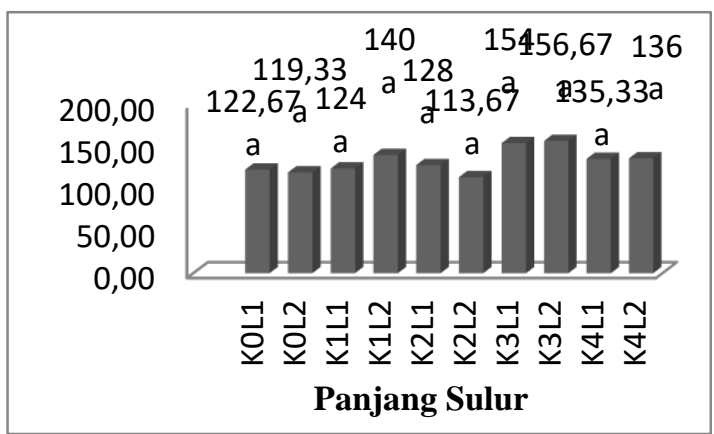

Gambar 4. Menunjukkan bahwa uji konsentrasi air kelapa $75 \%$ dan penyiraman diberi leri (K3L2) dengan rata-rata panjang sulur $156,67 \mathrm{~cm}$ tidak berbeda nyata dengan uji konsentrasi air kelapa $50 \%$ dan penyiraman diberi leri (K2L2) dengan ratarata panjang sulur 113,67 $\mathrm{cm}$ hal ini diduga karena persediaan unsur hara yang ada di dalam tanah dan tanaman sudah mencukupi untuk mendukung pertumbuhan setek ubi jalar jadi tidak diperlukan penyiraman air leri hingga mendekati panen, dan juga pada penelitian (Karimah dkk., 2013) yang menyatakan air kelapa konsentrasi $100 \%$ yang paling berpengaruh bagi pertumbuhan tanaman yaitu diteliti pada tanaman jati yang merupakan tanaman keras dan sudah berbeda spesies dengan tanaman ubi jalar.

Gambar 5. Diagram batang untuk berat brangkasan basah umur 16 MST akibat perlakuan uji konsentrasi air kelapa dan penyiraman leri.

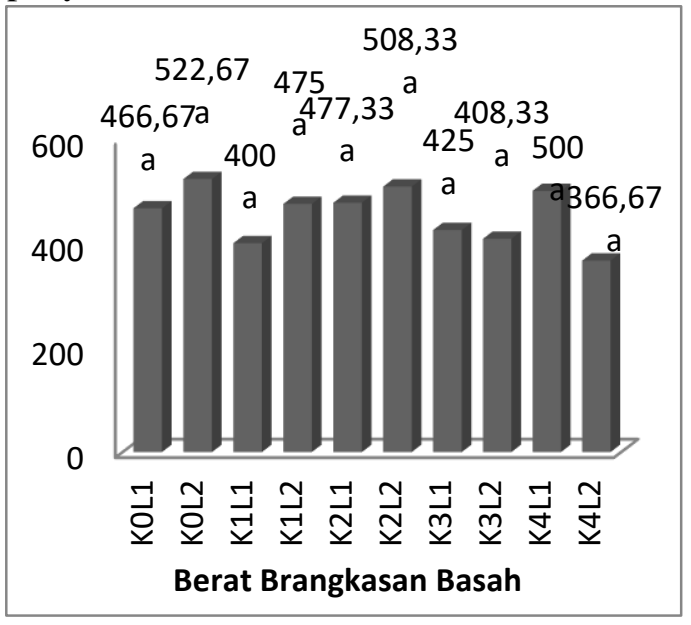

Gambar 5. Menunjukkan bahwa uji konsentrasi air kelapa 0\% dan penyiraman diberi leri (K0L2) dengan berat brangkasan basah 522,67 gram tidak berbeda nyata dengan uji konsentrasi air kelapa $100 \%$ dan penyiraman diberi leri (K2L2) dengan dengan berat brangkasan basah 366,67 gram, hal ini diduga karena persediaan unsur hara yang ada di dalam tanah dan tanaman sudah mencukupi untuk mendukung pertumbuhan setek ubi jalar jadi tidak diperlukan penyiraman air leri hingga mendekati panen, dan juga pada penelitian (Karimah dkk., 2013) yang menyatakan air kelapa konsentrasi 100\% yang paling berpengaruh bagi pertumbuhan tanaman yaitu diteliti pada tanaman jati yang merupakan tanaman keras dan sudah berbeda spesies dengan tanaman ubi jalar.

2. Uji konsentrasi air kelapa dan penyiraman leri terhadap hasil tanaman ubi jalar.

Gambar 6. Diagram batang untuk jumlah umbi umur 16 MST akibat perlakuan uji konsentrasi air kelapa dan penyiraman leri.

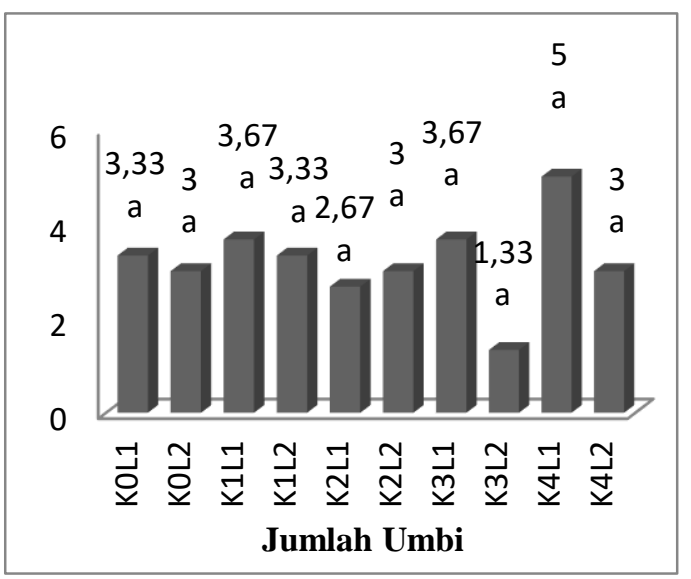

Gambar 6. Menunjukkan bahwa uji konsentrasi air kelapa $100 \%$ dan penyiraman tanpa diberi leri (K4L1) dengan rata- rata jumlah umbi 5 buah tidak berbeda nyata dengan uji konsentrasi air kelapa $75 \%$ dan penyiraman diberi leri (K3L2) dengan rata-rata jumlah umbi 1,33 buah hal ini diduga karena persediaan unsur hara yang ada di dalam tanah dan tanaman sudah mencukupi untuk mendukung pertumbuhan setek ubi jalar jadi tidak diperlukan penyiraman air leri hingga mendekati panen, dan juga pada penelitian (Karimah 
dkk., 2013) yang menyatakan air kelapa konsentrasi $100 \%$ yang paling berpengaruh bagi pertumbuhan tanaman yaitu diteliti pada tanaman jati yang merupakan tanaman keras dan sudah berbeda spesies dengan tanaman ubi jalar, dan juga pada penelitian G.M. dkk (2012 ) menyatakan bahwa limbah air cucian beras dapat meningkatkan pertumbuhan akar tanaman selada pada jenis dan Jurnal Biologi Edukasi Edisi 12, Volume 6 Nomor 1, Juni 2014, hal 34$3835 \mathrm{kadar}$ air cucian beras yang berbeda. Selanjutnya, pemberian air limbah ini juga meningkatkan pertumbuhan tanaman pacar air (Ratnadi dkk, 2014), dalam kutipan tersebut hanya digunakan pada penelitian pertumbuhan vegetatif tidak untuk penelitian pertumbuhan generatif.

Gambar 7. Diagram batang untuk volume umbi umur 16 MST akibat perlakuan uji konsentrasi air kelapa dan penyiraman leri.

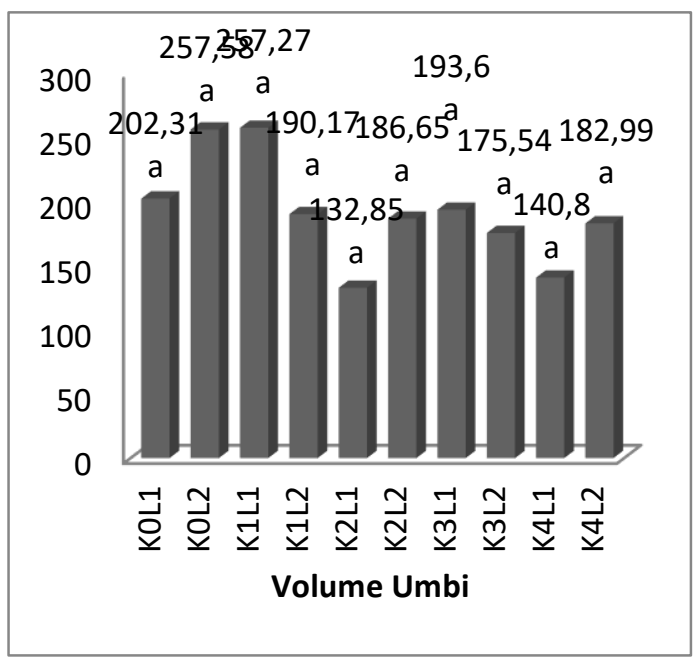

Gambar 7. Menunjukkan bahwa uji konsentrasi air kelapa 0\% dan penyiraman diberi leri (KOL2) dengan rata-rata volume umbi $257,58 \mathrm{~cm}^{3}$ tidak berbeda nyata dengan uji konsentrasi air kelapa 50\% dan penyiraman tanpa diberi leri (K2L1) dengan rata-rata volume umbi $132,85 \mathrm{~cm}^{3}$, hal ini diduga karena persediaan unsur hara yang ada di dalam tanah dan tanaman sudah mencukupi untuk mendukung pertumbuhan setek ubi jalar jadi tidak diperlukan penyiraman air leri hingga mendekati panen, dan juga pada penelitian (Karimah dkk., 2013) yang menyatakan air kelapa konsentrasi $100 \%$ yang paling berpengaruh bagi pertumbuhan tanaman yaitu diteliti pada tanaman jati yang merupakan tanaman keras dan sudah berbeda spesies dengan tanaman ubi jalar.

Gambar 8. Diagram batang untuk berat umbi umur 16 MST akibat perlakuan uji konsentrasi air kelapa dan penyiraman leri.

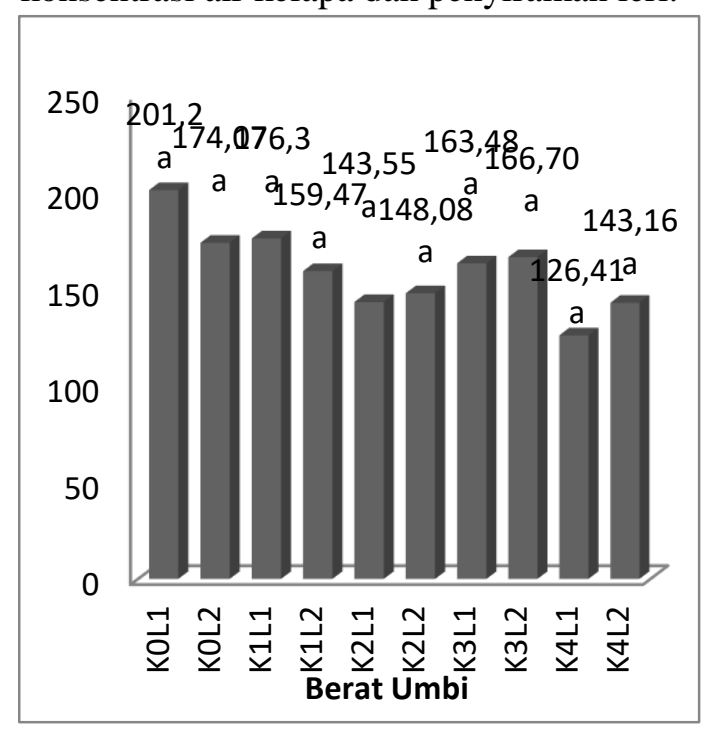

Gambar 8. Menunjukkan bahwa uji konsentrasi air kelapa 0\% dan penyiraman tanpa diberi leri (K0L2) dengan rata-rata berat umbi 201,2 gram tidak berbeda nyata dengan uji konsentrasi air kelapa $100 \%$ dan penyiraman tanpa diberi leri (K4L1) dengan rata-rata berat umbi 126,41 gram, hal ini diduga karena persediaan unsur hara yang ada di dalam tanah dan tanaman sudah mencukupi untuk mendukung pertumbuhan setek ubi jalar jadi tidak diperlukan penyiraman air leri hingga mendekati panen, dan juga pada penelitian (Karimah dkk., 2013) yang menyatakan air kelapa konsentrasi $100 \%$ yang paling berpengaruh bagi pertumbuhan tanaman yaitu diteliti pada tanaman jati yang merupakan tanaman keras dan sudah berbeda spesies dengan tanaman ubi jalar.

\section{KESIMPULAN DAN SARAN}

1. Berdasarkan hasil penelitian maka dapat disimpulkan bahwa:

Uji konsentrasi air kelapa dan penyiraman air leri tidak berpengaruh nyata terhadap komponen pertumbuhan dan hasil tanaman ubi jalar yaitu jumlah daun, jumlah tunas, panjang sulur, berat brangkasan basah , jumlah umbi, volume umbi, dan berat umbi, hal ini diduga karena persediaan unsur hara yang ada di dalam tanah 
dan tanaman sudah mencukupi untuk mendukung pertumbuhan setek ubi jalar jadi tidak diperlukan penyiraman air leri hingga mendekati panen, dan juga pada penelitian sebelumnya yang menyatakan air kelapa konsentrasi $100 \%$ yang paling berpengaruh bagi pertumbuhan tanaman yaitu diteliti pada tanaman jati yang merupakan tanaman keras dan sudah berbeda spesies dengan tanaman ubi jalar.

2. Saran

Berdasarkan penelitian di atas maka untuk mendapatkan pertumbuhan dan hasil terbaik pada tanaman ubi jalar sebaiknya mengunakan konsentrasi air kelapa yang sesuai dengan kebutuhan tanaman ubi jalar dan penyiraman air leri serta memperhatikan faktor lingkungan.

\section{DAFTAR PUSTAKA}

Asngad, A., Astuti, P., dan Rahmawati, I.N. 2013. Pemanfaatan Limbah Air Cucian Beras IR-36 dan IR-64 (Air Air leri) Untuk Pembuatan Sirup Melalui Fermentasi Dengan Penambahan Bunga Rosella Sebagai Pewarna Alami. Jurnal FKIPUNS (online) 10 (1). Tersedia dihttp://download.portalgaruda.org/ article.php?article $=139163 \& v a l=40$ 58. Diaksestanggal 2 Desember 2014.

Damardjati, D.S. dan S. Widowati, 1994. Pemanfaatan Ubi Jalar dalam Program Diversifikasi Guna Mensukseskan Swasembada Pangan. Dalam A. Winarto, Y.Widodo, SS. Antarlina, H. Pudjosantosa dan Sumarno (eds). Risalah Seminar Penerapan Teknologi Produksi dan Pasca Panen Ubi jalar untuk Mendukung Agro-Industri. Edisi khusus Balittan Malang No 3: 1-25.

Djamhuri, E. 2011. Pemanfaatan air kelapa untuk meningkatkan pertumbuhan setek pucukmeranti tembaga (Shorea leprosula Miq). Jurnal Silvikultur Tropika. 2(1):5-8 p.
Gardner, F.P., R.B. Pearce and R.L. Mitchell. 2006. Physiology of Crop Plant. Terjemahan Herawatu Susilo dan Subiyanto. "Fisiologi Tanaman Budidaya". Jakarta: Universitas Indonesia Press.

GARDNER, F.P., R.B. PEARCE, and R.L. MITCHELL. 1991. Fisiologi tanaman budidaya. Terjemahan oleh H.Susilo. Universitas Indonesia (UI Press). Jakarta.428 hlm.

G.M. Citra Wulandari, Muhartini, S., dan Trisnowati, S. 2012. Pengaruh Air CucianBeras Merah dan Beras Putih TerhadapPertumbuhan dan Hasil Selada (Lactucasativa L.). Jurnal Vegetalica (online),1(2). Tersedia dihttp://jurnal.ugm.ac.id/jbp/article/ download/1516/1313. Diakses pada tanggal 2Desember 2014.

Handiyanto, S., Hastuti, U.S., dan Prabaningtyas,S. 2013. Kajian Penggunaan Air CucianBeras Sebagai Bahan Media Pertumbuhan Biakan Murni Jamur Tiram Putih (Pleurotusostreatus var. Florida). Jurnal Universitas Malang (online), 1(1).Tersedia di http://jurnalonline.um.ac.id/article/d o/

Jusuf, M., A. Setiawan, D. Peters, C. Cargill, S.Mahalaya, J. Limbongan dan Subandi. 2007. Memperbaiki Efisiensi Produksi Ubi Jalar-Babi di Kabupaten Jaya wijaya, Papua. Makalah pada Sem. Nas. dan Ekspose Percepatan Inovasi Teknologi pertanian Spesifik Lokasi. Jayapura, 5-6 Juni, 2007.

Karimah, A., S. Purwanti., dan R. Rogomulyo. 2013. Kajian perendaman rimpang temulawak (Curcuma xanthorriza Roxb.) dalam urin sapi dan air kelapa untuk mempercepat pertunasan. Jurnal Vegetika. 2(2):1-6 p.

Limbongan, J. dan A. Soplanit. 2007. Ketersediaan Teknologi dan potensi Pengambangan Ubi Jalar (Ipomoea 
batatas L.) di Papua. Jurnal Litbang Pertanian 26(4):131-138.

Lawani. 2000. Teknik Pembibitan Dan Perbanyakan Vegetatif Tanaman. Bogor: World Agroforestry Centre.

Purwono, Purwanti. 2007. Sejarah Tanaman Ubi Jalar, Jurnal Semesta. Jakarta.

Puslitbangtan. 1999. Deskripsi Varietas Unggul Padidan Palawija 19931998. Pusat Penelitian danPengembangan Tanaman Pangan, Bogor.

Puslitbangtan. 2002. Deskripsi Varietas Unggul Padidan Palawija 20012002. Pusat Penelitian dan Pengembangan Tanaman Pangan, Bogor.

Ratnadi, N.W.Y., Sumardika, N.I.,dan Setiawan,G.A.N. 2014. Pengaruh Penyiraman AirCucian Beras dan Pupuk Urea DenganKonsentrasi Yang Berbeda TerhadapPertumbuhan Tanaman Pacar Air(Impatiens balsamina L.). Jurnal JurusanPendidikan Biologi (online), 1(1).Tersedia dihttp://ejournal.undiksha.ac.id/inde x.php/JJPB/article/view/3276.

Diakses tanggal 2Desember 2014.

Tsuno,Y. 1980. Sweet potato, nutrient physiology and cultivation. Fac.of Agric. Ehime Univ., Japan.Ed. : Inter. Potash Institute berne, Switzerland : 1-7.

Untari, R. dan Dwi M. P. 2006. Pengaruh Bahan Organik dan NAA terhadap Pertumbuhan Anggrek Hitam (Coelogyne pandurata Lindl.) dalam Kultur in Vitro. Bogor : Fakultas Kehutanan, Institut Pertanian Bogor.

Warisno. 2004. Mudah dan Praktis Membuat Nata de Coco. Jakarta : Argomedia Pustaka.

Wattimena, G.A. 2005. Zat Pengatur Tumbuh Tanaman. Bogor: PAU Bioteknologi 